\title{
IMPROVING THE EFFICIENCY OF THE SOLAR STILL USING ELECTRICAL HEATERS POWERED BY SOLAR PANEL AND AN OUTSIDE CONDENSER SOLAR PANEL AND AN OUTSIDE CONDENSER
}

\section{Mohamed Nabih Omar* and Mahmoud Hassan Keshek*}

\begin{abstract}
Water and energy are two important factors that govern the lives of humanity and promote civilization. In Egypt we have a big problem in the fresh water and the energy. The main objective of this study was increased the fresh water produce by new design of the solar still using electrical heaters powered by solar Panel and an outside condenser. In order to reach the objective of the study two types of distiller units was design, the first one was conventional unit and the second a new model of solar still with heaters and separating the condensation unit from the evaporation unit. To improve the thermal efficiency of the proposed hybrid solar still (PV/T) systems, the cooling process was carried out to the condenser and the thermal energy generated was recovered during the condensation process. Measurements included that, All the temperatures (saline water, preheated water, basin water, basin, glass cover, panel, ambient), the solar irradiance, Voltage and current, electricity generated from photocells, Water vapour pressure, glass cover transmission, solar radiation, fresh water production, over all thermal efficiency of the still. The experiments are carried out in the eight typical clear sunny days. The results showed that the maximum and the minimum irradiance were $7488 \mathrm{~W} / \mathrm{m} 2$.day and $7140 \mathrm{~W} / \mathrm{m} 2$.day. That the maximum solar energy (26.959 MJ/m2/day), and minimum solar energy (25.704 MJ/m2/day). The maximum ambient temperature was (42 $\left.{ }^{\circ} \mathrm{C}\right)$. It also found that the minimum specific energy consumption was $3.820 \mathrm{MJ} / \mathrm{L}$ that means the maximum utilization of energy with the proposed hybrid active $(P V / T)$ solar still with heater and divided feed. The maximum specific energy consumption was 7.483MJ/L, it was found for the conventional solar still without heater and Total feeding rate with minimum energy efficiency.
\end{abstract}

\footnotetext{
$\overline{~ a ~ A g r i c u l t u r a l ~ E n g i n e e r i n g ~ D e p a r t m e n t, ~ F a c u l t y ~ o f ~ A g r i c u l t u r e, ~ M e n o u f i a ~ U n i v e r s i t y, ~} 32511$ Shebin EL-Kom, Egypt.
} 
The proposed hybrid saved about 49\% of the energy consumption to produce a liter of pure water. The minimum productivity of fresh water was estimated about $3.435 \mathrm{l} / \mathrm{m} 2$ day, it was provided in the system of conventional solar still. The maximum productivity of fresh water in the system of proposed hybrid active (PV/T) solar still with heater and divided feed was estimated about $8.571 \mathrm{l} / \mathrm{m} 2$ day. The increasing rate in the productivity about $149.50 \%$ was achieved using by using proposed solar still. The overall thermal efficiency was increased by $36 \%$ of the proposed hybrid active (PV/T) solar still is much higher than the conventional. The fresh water produced from the new design of distiller unit with highly efficiency can be use within Hydroponics in coastal area.

Keywords: Solar still, Efficiency, productivity, Solar Panel.

\section{INTRODUCTION}

$\mathrm{W}$ ater and energy are two important commodities that govern the lives of humanity and promote civilization. In Egypt we have a big problem in the fresh water and the energy. We need large amounts of water for the reclamation of new land to meet the needs of the growing amounts of food. The process of desalination of seawater using solar energy will provide additional quantities of water that can be exploited to expand the reclamation and cultivation of new lands (horizontal expansion) especially in the coastal areas. Increasing the production of fresh water can be done by improving the efficiency of the seawater desalination process There are many factors that effect on the productivity of solar distillers. These factors include the intensity of solar radiation, wind speed, ambient temperature, temperature difference between distillation and water cover in distillation basin, water surface area, water depth, water feeding temperature, absorption plate area and glass cover angle Nafey et al., (2000). Some factors cannot be change because they are natural factors as the intensity of solar radiation, Wind speed and environmental temperature. Other factors can be change to increase the productivity of solar distillers. Many studies are still conducted to improve the productivity of distillates from solar energy Tripathi et al., (2006). 
1- The Solar radiation

The rays of the sun which arrives to the surfaces are divided into two parts: the direct rays that penetrate the obstacles until they reach to the surface of the earth. And the diffuse radiation, which is reflected by dust, water vapor and gases in the atmosphere and ranges from about 10 to $20 \%$ of the total radiation Matthews (2009). The intensity of solar radiation varies depending on the place and the time of the year where it incidence. The values of solar radiation intensity which can be used in the desalination process can be predicted for any place and time using the mathematical simulation model Taha (2010). The intensity of solar radiation in Shibin El-Kom, Menoufia, Egypt was increased by about $40 \%$ in the summer from winter, which requires a preventive measure to maintain the stability of the amount of water resulting from the distillation process at that time Taha (2010), Omar (2011) and Salam (2011). The intensity of solar radiation mainly affects the temperature of the receiving surface and therefore affects any process that depends on the heating system, as happens in the process of solar water desalination Akash et al., (2000).

2- $\quad$ Used the external energy from Solar panel.

Temperature is the primary factor in desalination of seawater by solar energy, but because of the instability of the intensity of solar radiation, the temperature is unstable, therefore the use of external energy source is to maintain and even to increase the efficiency of solar distillates Zurigat et al., (2004). The process of desalination is divided into two processes: vaporization and steam condensation. Both processes are affected by the temperature Pal et al., (2017). In the distillation process, evaporation is increases by increasing the temperature and the process of condensation is decreases with increasing the temperature Sharshir et al., (2016). The distillation efficiency was increased by $157 \%$ by increasing the temperature inside the distiller by using a 300W electric heater Salam (2011).

To increase the efficiency of the distillers, an external source of heat is added (the heating process). But due to the high prices of conventional energy as well as the process of distillation in the coastal areas, which are remote, therefore, it is preferable to use solar cells to produce the electric 
energy needed to operate the heaters to increase the efficiency of distillation process, As well as to reduce the cost of fresh water production Singh et al.,(2004). The daily yield from the proposed hybrid active (PV/T) solar still is 6 times more than the conventional passive still kuma et al., (2017).

3- Effect of surface area of absorbent and depth of water inside the distiller.

The evaporation rate of the distilled water is relatively proportional to the surface area of water exposed to solar energy. As a result, increasing the surface area of water in the basin improves the production efficiency of fresh water Hiroshi et al., (2009). The depth of the water in the basin strongly affects in the distill efficiency, since water depth is inversely proportional to productivity Tripathi e al.,( 2004), Tiwari e al., (2007) and Tiwari et al., (2009). It has been found that the lowest depth of water has reached maximum productivity when the solar energy is stable and a dry spot will occur. This is why maintaining the minimum achievable depth is important Khalifa et al.,(2009). The performance of the proposed active hybrid PV/T still is with $0.05 \mathrm{~m}\left(0.335 \mathrm{~L} / \mathrm{m}^{2} / \mathrm{MJ} /\right.$ day $)$ water depth is better than the still with $0.10 \mathrm{~m}\left(0.228 \mathrm{~L} / \mathrm{m}^{2} / \mathrm{MJ} /\right.$ day $)$ and $0.15 \mathrm{~m}\left(0.165 \mathrm{~L} / \mathrm{m}^{2} / \mathrm{MJ} /\right.$ day $)$ water depths kuma et al., (2017).

4- Temperature of water in the basin.

The temperature of the saline water within the basin controls the rate of evaporation. Large amounts of solar energy (additional solar collectors) may be needed to increase the water temperature to increase the rate of thermal heating on the surface of water Velmurugan et al., (2011). The amount of condensed water depends heavily on the temperature difference between the glass cover and the water. Also increasing the temperature of water all this leads to an increase in production Setoodeh e al.,( 2011) and Shukla et al., (2005). When the difference in temperature increases from $6^{\circ} \mathrm{C}$ to $11^{\circ} \mathrm{C}$, the productivity increases from $0.1 \mathrm{~L} / \mathrm{m}^{2} / \mathrm{h}$ to reach $0.85 \mathrm{~L} / \mathrm{m}^{2} / \mathrm{h}$. When a difference of $10^{\circ} \mathrm{C}$ was achieved, the yield was $0.8 \mathrm{~L} / \mathrm{m}^{2} / \mathrm{h}$ when the salt water temperature was $70^{\circ} \mathrm{C}$, while the productivity, up to $0.1 \mathrm{~L} / \mathrm{m}^{2} / \mathrm{h}$ when the temperature of salt water was $30^{\circ} \mathrm{C}$ Rubioa et al., (2000). 
The effects of environmental factors vary according to the opinions of a number of researchers. Voropoulos et al., (2003) reported that productivity was improved by reducing air temperature in the environment. El-Sebaii et al (2004) and Badran et al., (2007) reported that improved productivity by increasing wind speed. All this leads to a difference in temperature between the glass cover and saline solution. Improving the production of fresh water by $8.2 \%$ with increased the ambient air temperature of $10{ }^{\circ} \mathrm{C}$ Al-Hinai et al., (2002).

5- Insulation of solar still.

The thickness and the material of the insulation are high effects in a solar still Al-Karaghouli et al., (2004) and Khalifa et al., (2009). Karaghouli et al.,(2004) reported that the average daily output was $2.46 \mathrm{~kg} / \mathrm{m}^{2} / \mathrm{d}$ in June for a non-insulated still whereas for an insulated still it was 2.84 $\mathrm{kg} / \mathrm{m}^{2} / \mathrm{d}$. Khalifa et al., (2009) Suggested that the productivity could be achieved with increase of $80 \%$ by selection of appropriate insulation 6- Effect of angle and thickness of covering materials

Inclination angle of the cover, which increased the transmittance the solar energy and leads to the maximum value of production was equal to the latitude angle of the place Singh et al., (2004). Based on an understanding of mathematical analysis, glass cover performance can be improved at different angles Akash (2000). It was found that the $35^{\circ}$ angle of inclination, equal to the latitude angle of this place, resulted in the maximum return of fresh water. Tripathi et al., (2004) Experiments on latitude $\left(31.57^{\circ} \mathrm{N}\right)$ and the effect of the inclination on the performance of solar collectors, found that tilting the covers alone could change the output by about $63 \%$.

The heat transfer through the glass cover improved when the thickness decreased, and the thermal conductivity increased. Experimental results showed that solar energy production increased by $16.5 \%$ with a glass cover of $3 \mathrm{~mm}$ using the thickness from the glass $6 \mathrm{~mm}$ Kaushal and Varun (2010). Glass cover is preferred because of the large transmittance solar energy and application of different angles of the site and its longterm use, while plastics (such as polyethylene) can be used for short-term use Pal et al., (2017). So the main objective of this study is to increasing the fresh water produced and improving the efficiency of the seawater 
desalination by design a new solar still with electrical heaters powered by solar panel and an outside condenser Sharshir et al., ( 2016).

\section{MATERIALS AND METHODS}

\subsection{Design of the proposed solar still}

The desalination of seawater using solar energy depends on two processes, the evaporation process and the condensation process, which are the opposite of each other. Increasing the evaporation depends on adding the heat energy and to reach the maximum efficiency of the condensation must be a cooling process for water vapor. From the above it is clear that the two processes are opposite. In order to reach the objective of the study, a new model of solar still with electrical heaters powered from solar panel was designed, based on separating the condensation unit from the evaporation unit to increase the evaporation process in addition to maximum efficiency of the condensation and recycle of the heat gained from condensation processes.

\subsubsection{Description of the solar still units.}

For validating the proposed work, two solar stills were designed and fabricated.

a) Conventional solar still (SDU).

The first one: the conventional solar still system with a single slope type SDU and basin area $1 \mathrm{~m}^{2}(1 \mathrm{~m} \times 1 \mathrm{~m})$ is designed and fabricated with the high-side wall height is $75 \mathrm{~cm}$ and the low-side wall height is $15 \mathrm{~cm}$. It is the passive form of solar distiller unit (SDU) which receives direct solar heat from sun that is directly utilized to vaporize the saline water. To increase the absorption of heat from the sun black paint is coated on the full surface of the basin (bottom and side wall) from inside and its direction is heading to the south. Single sheets of Extruded polystyrene material foam boards with $3 \mathrm{~cm}$ thickness are used to insulate the basin from all outer sides (bottom and side wall). This provision of insulation reduces the loss of heat from the still to the atmosphere. A glass sheet of 3 $\mathrm{mm}$ is used to cover the basin from the top, placed at an angle of $30^{\circ}$ horizontally, that is the approximate latitude angel of the location. Fig. 1 shows the Schematic views for the single slope (SDU) of the conventional solar desalination system. 


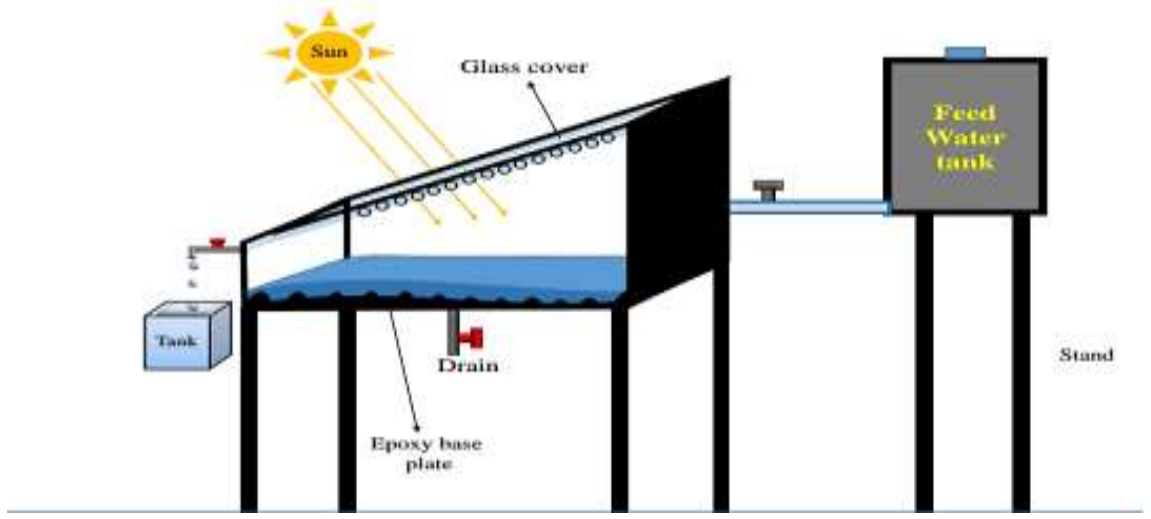

Fig. 1 Schematic view of the conventional solar still.

b) Proposed hybrid (PV/T) solar still with heaters and outside condenser.

A cross-section and photograph of the proposed solar still with a separated condenser unit is shown in Fig. 2 ( $a, b)$. The new model was designed, based on separating the condensation unit from the evaporation unit. The evaporation unit has the same designed and dimensions of the conventional solar distiller. The total area under the condenser was $1 \mathrm{~m}^{2}$ with the dimensions of $1 \times 1 \mathrm{~m}$.

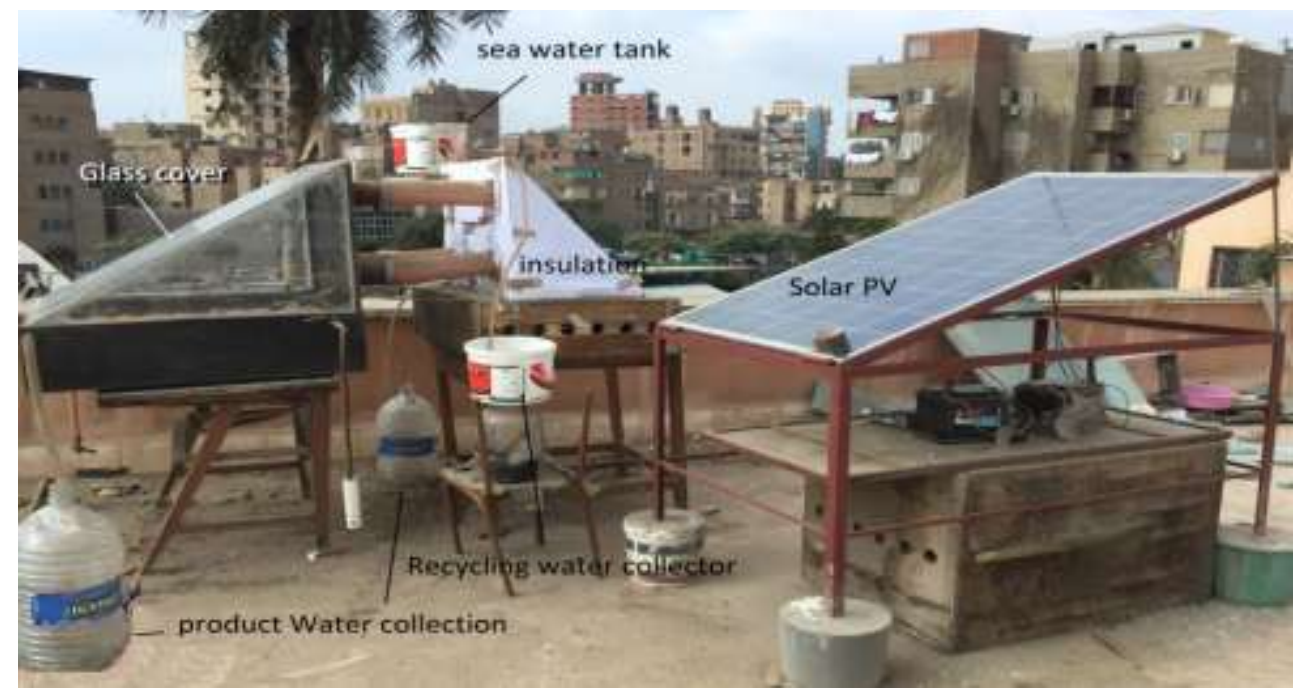

Fig. 2 (a) Photographic view of the overall experimental setup and the condensate water formation in stills

In the case of active solar Distiller, it uses an external heat source to increasing the water temperature in the basin for increasing the evaporation. Water vapour production is increasing by raise the saline water temperature in the basin by the electric heaters and absorption of solar radiation by the 
absorbent surface. Three electric heaters with $50 \mathrm{~W}$ per one are used per square meter of the basin area and the electric power supply from solar panel (PV) module. Water vapour production under the glass cover of the distiller was pushed out using a suction fan and passed through a watercooled condensation unit. Three fans with $5 \mathrm{~W}$ per one are used per square meter of the basin area. The fans are important for, as it known that, decreasing the air pressure in the basin cause water would evaporate faster due to the decreases in water evaporation temperature.

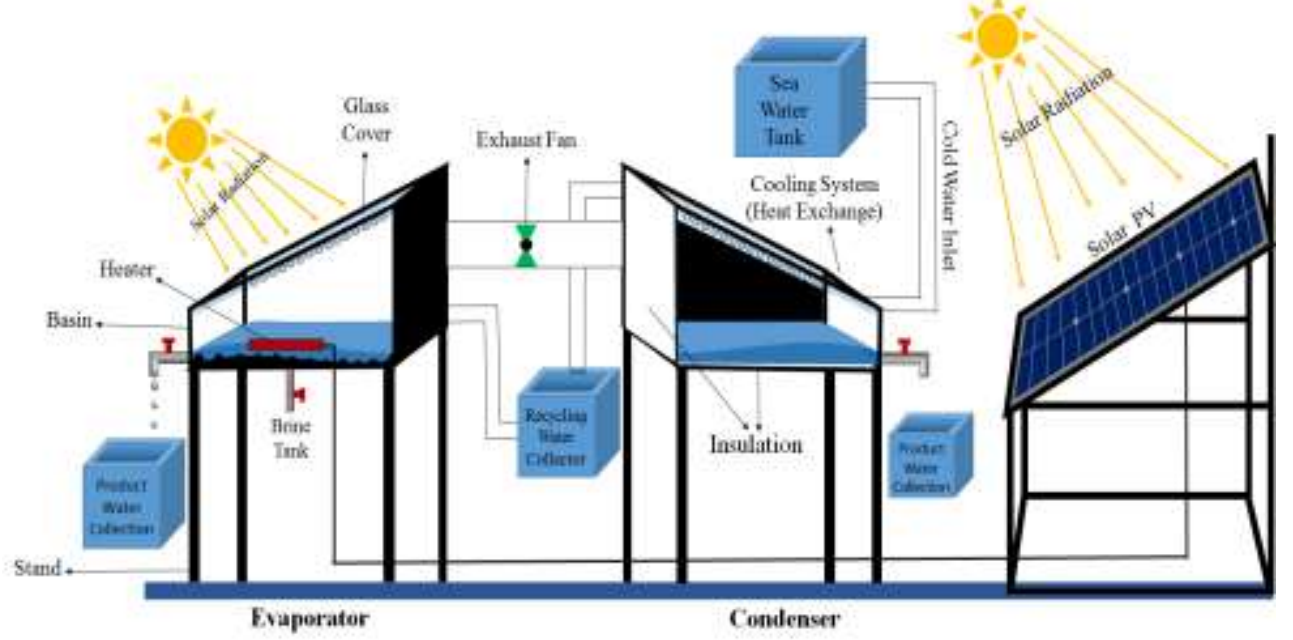

Fig. 2 (b) Schematic view of the proposed hybrid (PV/T) active solar with heater

\subsubsection{The advantages of the proposed hybrid (PV/T) solar distiller.}

1- loss of latent heat of condensation to the environment is minimized, and saved in a condenser;

2- The heat of vaporisation which is not lost to the environment but saved in the condenser used to preheat saline water for recycling;

3- The new sea water used for cooling water vapour in the condensation unit was Pre-heated from the condenser and supplies the next batch of re-charge for the still basin;

4- the different temperature between water in the basin and the glass cover increases;

5- Lower vapor water pressure for the air within the evaporation unit; and

6- Improvement the transmittance where is the percentage of solar radiation passing through the glass cover arrives to the maximum. 
The first advantage gives the opportunity to recycle the heat of condensation, and the latter two results in faster evaporation of water from the basin, and an increased yield of the distilled water. They all increase the overall thermal efficiency of the distiller. The second advantage comes from the electrical heaters that powered from the solar panel. The third advantage was done by used the exhaust fan. The purpose of the fan is to Pull the water vapour from the basin and transfer to the condensation unit, and decrease the pressure and water condensation under the glass cover to increasing the solar radiation.

\subsection{Characteristics of solar PV.}

The heaters are located above the bottom of still basin and powered by a photovoltaic (PV) system. The PV system consists of PV cell, battery and charge controller. For the proposed work, a PV panel mono-crystalline type photovoltaic module with $250 \mathrm{~W}, 18 \%$ efficiency and $1.6 \mathrm{~m}^{2}$ area is used to operate the suction fan and heaters. Open circuit voltage $22 \mathrm{~V}$, short-circuit current $3.4 \mathrm{~A}$ and working voltage $17.5 \mathrm{~V}$. the system consists Inverter with $600 \mathrm{~W}$ capacity and battery to storage the electricity.

The ambient temperature effected of the energy production from solar PV.

Temperature coefficient $\left(\mathrm{C}_{\mathrm{v}}\right)$ and ambient temperature $\left(\mathrm{T}_{\mathrm{a}}\right)$ decides the actual output of the solar PV panel. The temperature coefficient is a constant which may vary slightly for different cells manufacturers and the ambient temperature is the present atmospheric temperature at the panel. Eq. (1) kuma et al., (2017) gives the relation between the ambient temperature and the panel output.

$$
\text { Actual voltage }=V_{m p}+\left[C_{v} \times\left(T_{a}-25\right)\right]
$$

The temperature coefficient of this module is $-0.36 \% /{ }^{\circ} \mathrm{C}$ of the open circuit voltage.

\subsection{Analysis of the thermal network for the still with an outside condenser.}

In the case of the alternative solar still the qc,b-g, qr,b-g and qe are lost through the glass cover but in the case of the solar still with an outside condenser only qc,b-g and qr,b-g are lost through the glass 
cover while qe is partially saved in the condenser Monowe et al., (2011).

$$
\begin{aligned}
& q_{e}=q_{\text {conden }}+q_{\text {sensbl }} \\
& q_{\text {conden }}=M_{t} L \\
& q_{\text {sensbl }}=M_{t} C_{P}\left(T_{i c}-T_{a}\right)
\end{aligned}
$$

Where the $\mathrm{q}_{\mathrm{e}}$ is the heat of vaporisation saved in the condenser to preheat saline water for recycling which is not lost to the environment, $\mathrm{q}_{\text {conden }}$ is the latent heat of condensation; $\mathrm{q}_{\text {sensble }}$ is the sensible heat of the water vapour from the basin, Mt amount of daly fresh water production and $\mathrm{L}$ is the vaporization latent heat.

The heat energy recycled from condensation Monowe et al., (2011).

$$
\begin{aligned}
& q_{e}=q_{l}+q_{c} \\
& q_{c}=q_{\text {conden }}+q_{\text {sensbl }}-q_{l}
\end{aligned}
$$

Where the $\mathrm{q}_{l}$ is the heat energy lost from the condenser due to conduction; $\mathrm{q}_{\mathrm{c}}$ is the recycled heat of condensation. To calculate the heat loss through a unit's surface can be obtained by following equation Omar et al., (2018):

$$
q_{l=} U A_{w}\left(T_{w i}-T_{a}\right)
$$

Where $\mathrm{q}_{l}$ is heat loss through a unit surface of walls, the $\mathrm{U}$ is the total heat transfer coefficient of wall, $\mathrm{T}_{w i}$ is the water vapour temperature in the condensation unit, and $\mathrm{T}_{\mathrm{a}}$ is mean outside air temperature.

The total heat transfer coefficient for the structures can be computed Omar et al., (2018) as:

$$
U_{w}=\frac{1}{\left(\frac{1}{\alpha_{i}}+R_{w}++\frac{1}{\alpha_{o}}\right)}
$$

\subsection{Efficiency of the energy recycles from condensation.}

The thermal efficiency ( $\eta_{\text {cond }}$ ) for the condenser unit is represented as the ration between energy output from condenser (the energy recycle from condensation) to the input energy (the heat energy of the vaporization) which is given by Monowe et al., (2011) as follows:

$$
\begin{aligned}
\eta_{\text {cond }} & =\frac{q_{c}}{q_{e}} \\
\eta_{\text {cond }} & =\frac{q_{\text {cond }}+q_{\text {sens }}-q_{l}}{q_{\text {cond }}+q_{\text {sens }}} \times 100
\end{aligned}
$$

Estimate the temperature of the hourly water output from the condenser

$$
q_{c}=\sum_{1}^{12} m_{h} c_{p}\left(T_{w}^{-}-T_{w}\right)
$$




$$
T_{w}^{-}=\frac{q_{c}}{m_{h} C_{p}}+T_{w}
$$

Estimate the amount of hourly water used to cooling the condenser

$$
m_{h}=\frac{I_{s, h}}{I_{s}} m_{s w}
$$

Where $\mathrm{m}_{\boldsymbol{h}}$ is amount of hourly water used to cooling the condenser and it's a ration of the total saline water entering to the still, $\mathrm{I}_{s, \boldsymbol{h}}$ hourly solar radiation, $\mathrm{I}_{s}$ total solar radiation and $\mathrm{m}_{s w}$ is the total saline water entering to the still.

\subsection{Daily efficiency of solar (passive and active) still and PV panel}

- The thermal efficiency of the passive solar still

The overall thermal efficiency $\left(\eta_{\text {overall,th }}\right)$ for S-SSU is represented as the ratio between net energy output from solar still to net available solar radiation intensity which is given by Tiwari et al,. (2007) as follows:

$$
\eta_{p-s s}=\frac{(\text { daily yield }) \times L}{A_{s} \times \sum I_{s} \times 3600}
$$

Where $\mathrm{L}$ is the vaporization latent heat and is given as follows:

$$
L=2.4935 \times 10^{6}\left(1-9.4779 \times 10^{-4} T_{a}+1.3132 \times 10^{-7} T_{a}^{2}-\right.
$$

\section{$\left.4.7974 \times 10^{-9} T_{a}^{3}\right) \quad(15)$}

- The thermal efficiency of the proposed hybrid active (PV/T)

\section{solar still.}

The overall efficiency of the proposed still is calculated by summing the thermal efficiency of the active still and the electrical efficiency of the solar PV. With the reference of Tiwari et al., (2002), the overall efficiency is calculated by the following equations.

$$
\eta_{A-s S-H P V T}=\frac{(\text { daily yield }) \times L}{A_{s} \times \sum I_{s} \times 3600+A_{p \times} \sum I_{p} \times 3600}
$$

Where $\mathrm{L}$ is the vaporization latent heat

Electrical efficiency of PVT module is as follows:

$$
\eta_{e}=\frac{F F \times I_{s c} \times V_{o c}}{A_{p} \times I_{p}}
$$

Where $\mathrm{FF}=$ fill factor for solar cell $=0.8$

The equivalent thermal efficiency of PVT is given by Je et al.,(2007) as follows:

$$
\eta_{\text {eth }}=\frac{\eta_{e}}{0.38}
$$

The overall thermal efficiency of A-SS-HPVT solar distiller unit is given by

$$
\eta_{\text {overall,th }}=\eta_{A-S S-H P V T}+\eta_{\text {eth }}
$$


The daily overall thermal energy efficiency is given by Singh et al., (2016b) as given by the Eqs. (20) as follows

$$
\begin{aligned}
& \eta_{\text {daily,overallthermal }}=\frac{\sum_{i=1}^{24}\left(m_{e w} \times L\right)}{\sum_{i=1}^{24}\left[A_{S} \times I_{S}+A_{p} \times I_{p}\right] \times 3600} \times 100+ \\
& \frac{0.88 \times \sum_{i=1}^{24} V_{o c} \times I_{s c}}{0.38 \times \sum_{i=1}^{24}\left(A_{p} \times I_{p}\right)} \times 100
\end{aligned}
$$

\subsection{Experimental procedure.}

All the experiments are conducted and carried out under climate conditions on the building rooftops of Agricultural College, Minofiya University, Shibin El-Kom, Minofiya, Egypt (Geographically, the chosen place's latitude angle is $30^{\circ} 54^{\prime}$ degrees). The readings of the experiments are taken on an hourly basis from 7 AM to 7 AM (next day) during summer 2018 season through May and June months. To keep the efficiency of the still at a high level, saline water must be removed from the evaporator every day to operate the still and to put the next batch of new saline water into the still in the morning.

For validating the proposed technique experimentally, the stills were tested under tow variables: four different modes of operation and two different feed systems of water.

\subsubsection{The different modes.}

1- Alternative unit: the still operating as a passive conventional solar still

2- Alternative unit with heaters: the still operating as a conventional solar still and adding external sources of the energy to raise the temperature of water in the basin. Electrical heaters that powered from the solar panel were used.

3- Proposed still unit: a new model solar still was designed, based on separating the condensation unit from the evaporation unit.

4- Proposed still unit with heaters: the new model of solar still was used with electric heaters whose energy is derived from the unit of solar panel cells to increase the evaporation process in addition to the solar energy used

\subsubsection{The two different feed systems to the basin of Saline water.}

In the experimental study used the initial depth of water in the basin was equal to $4.5 \mathrm{~cm}$, i.e. the basin contained 451 of saline water 
according to kuma et al., (2017) and Monowe et.al., (2011). The 45 litter of saline water entering to the different modes of basin stills with two different feed systems of water as following:

1- Entering the 45 liter of saline water one time at the morning

2- Divide the 45 liter of saline water entering into 3 parts per the sunny day every part equal 15 litter. That's means, the solar day is divided into three parts the water depth is $0.015 \mathrm{~m}$ ( 15 liter) in the first period of the day, $0.030 \mathrm{~m}$ (30 liter) in the second period, and $0.045 \mathrm{~m}$ (45liter) in the third period.

\subsection{Measurements.}

\section{Measuring and Instrumentation}

Various measuring instruments are used to measure the required parameters for hybrid PV/T still which are as follows.

- Digital thermometer: All the temperatures (saline water, preheated water, basin water, basin, glass cover, panel, ambient) are measured using individual digital thermometer TPM-10. It has a resolution of $0.1^{\circ} \mathrm{C}$. These sensors are integrated with a controller to read data.

- Pyranometer: For measuring the solar irradiance LX-101A digital meter is used.

- Measuring flask: Distillate output water is finally collected and measured using a calibrated flask.

- Voltage and current measurements: Panel's voltage (Voc, VL) and current (Isc, IL) are sensed by using a voltage divider and current sensor ACS714 modules which are coupled with a controller for Maximum Power Point Tracking (MPPT)

- Water vapour pressure, kpa [35]

$$
P_{w v}=0.61078 \times \exp \left[\frac{17.2693882 \times T_{b i s}}{T_{b i s}+237.3}\right]
$$

Where $T_{\text {bis }}$ is the saline water temperatures in the basin

- Transmittance: Percentage of solar radiation passing through the glass cover .Influence of glass cover transmission radiation, transmission coefficient, $\tau$, was calculated from the ratio of inside to outside solar irradiance $\left(\tau=\mathrm{R}_{\mathrm{s}, \mathrm{i}} / \mathrm{R}_{\mathrm{s}, \mathrm{o}}\right)$. 


\section{RESULTS AND DISCUSSION}

The experiments are carried out in the eight typical clear sunny days during the months of May and June 2018. The experimental readings are taken for various still moods at different water feeding rate system; 0.045 $\mathrm{m}$ one time and $(0.015 \mathrm{~m}, 0.030 \mathrm{~m}$, and $0.045 \mathrm{~m})$. The water preheating, condensation cover cooling and electrical heaters are the three major parts that validate the proposed method. For validating the proposed still design is compared with the conventional still.

\subsection{Hourly variation of basin water and ambient temperature for experimental days}

Air temperature in the basin water and ambient is considered a very important environmental condition affecting on the fresh water production from the still. Fig. 3a-b shows that the maximum ambient air temperature reached to $42{ }^{\circ} \mathrm{C}$ at $2 \mathrm{pm}$ and $41{ }^{\circ} \mathrm{C}$ at $2 \mathrm{pm}$ during the days of the study for the conventional and proposed still respectively. The minimum temperature recorded during the study days was $26{ }^{\circ} \mathrm{C}$ at 5 am and $25{ }^{\circ} \mathrm{C}$ at 5 am for the conventional and proposed still respectively. When increasing the intensity of solar radiation, it affects in increasing the temperature inside the still and increase in the fresh water production, it is evident during the period of back.

The maximum temperature of basin water for the conventional still was $77{ }^{\circ} \mathrm{C}$ when using electric heaters and intermittent feeding system. The maximum temperature was $69{ }^{\circ} \mathrm{C}$ with conventional still during the days of the study. But in the proposed hybrid PV/T still the maximum temperature of basin water reached to $\mathbf{7 8}^{\circ} \mathrm{C}$ although the use of the exhaust fans which lead to a reduction of pressure and temperature. But the cause of the increasing the temperature is due to increasing in the ratio of solar radiation transmission from the cover (the transmission coefficient for the proposed hybrid active (PV/T) solar still was higher than the conventional solar still), and use of the energy recycles from condensation from the condenser cooling process. The use of the feeding system in stages has the greatest effect in raising the temperature inside the evaporation unit. As well as the use of electric heaters all this leads to increase the rate of evaporation. 

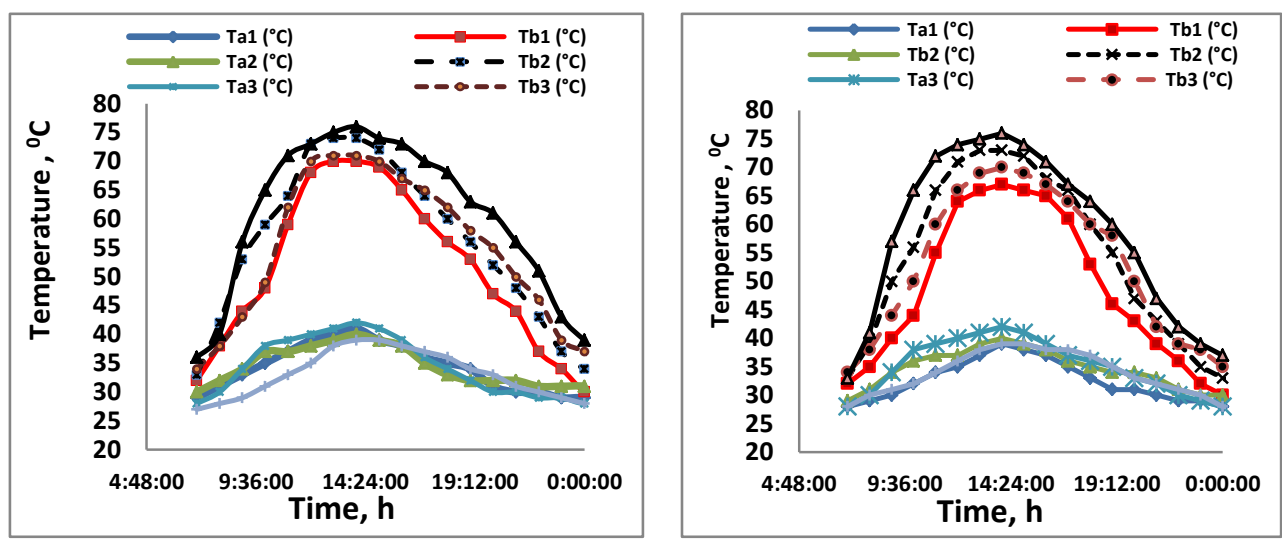

Fig. 3 Hourly variation of basin water and ambient temperature for experimental days for (a) conventional sill (b) for proposed still

\subsection{Hourly variation of solar irradiance}

Fig. $4 \mathrm{a}-\mathrm{b}$ gives the hourly observations for the four experimental days at two different still. The solar intensity varies time to time which is noted periodically. The maximum solar radiation intensity was about 1 to $2 \mathrm{pm}$ almost all days and the maximum values for all days varied between $\mathbf{9 0 0}$ to $950 \mathrm{~W} / \mathrm{m}^{2}$.
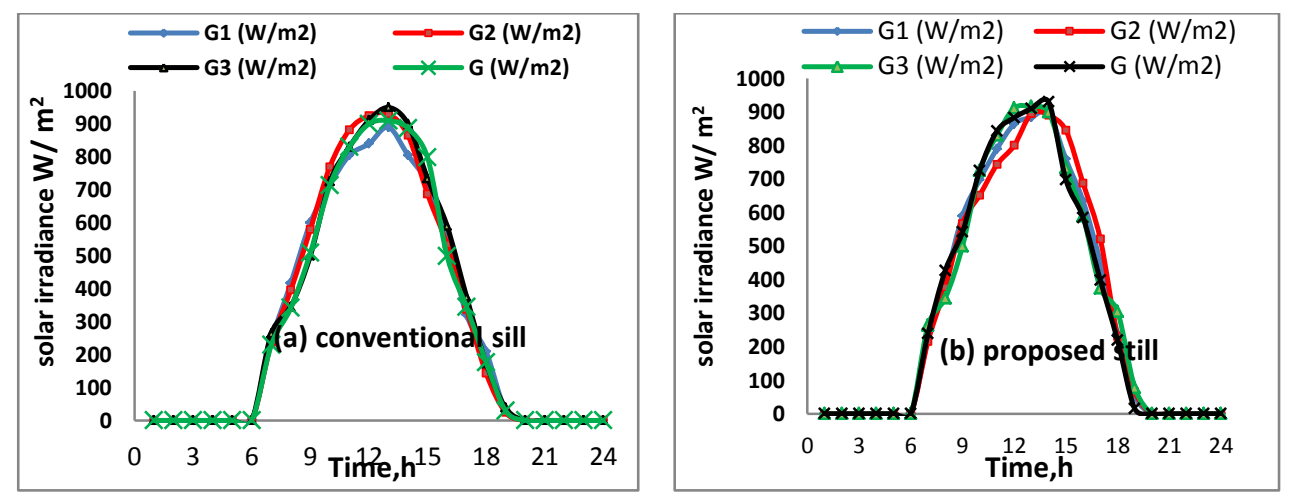

Fig. 4 Hourly variation of solar irradiance for (a) conventional sill (b) proposed still

From fig. 4 can see that, 25th May and 9th June have the maximum irradiance $\left(950 \mathrm{~W} / \mathrm{m}^{2}\right)$. It is clear that the solar irradiance falling during the selected days the differences between them were very small, which denies the existence of a relationship between the difference in productivity and values of the intensity of solar radiation. As seen in figures, the increase in radiation intensity increased the temperature of water in tank, and consequently the amount of vaporization increased. 


\section{3. cover transmission affected in the solar irradiance prevent}

Transmission of the still cover has a great effect on the radiation intensity inside he still. The increasing of the radiation intensity leads to raise the temperature of water in basin, and consequently the amount of vaporization increased. Two days were chosen each day represent the study days for each type of still under study. Table 1 shows the hourly solar radiation, transmission coefficient and the amount and the rate of solar irradiance prevent from the stills cover. The data shows that the transmission coefficient for the proposed hybrid active (PV/T) solar still was higher than the conventional solar still transmission coefficient. This was due to the reduced the condensate water on the inner surface of the glass cover in the proposed model, due to the transfer of water vapor to the condenser. The Maximum value of transmission coefficient was 0.65 and 0.85 for the proposed hybrid and the conventional solar still respectively. The rate of solar irradiance prevent from the cover was $40.48 \%$ and $24.81 \%$ for the conventional cover and the proposed hybrid cover respectively, means that about $16 \%$ increase in the ratio of solar radiation transmission from the cover and it represents a great value.

Table 1 the hourly solar irradiance, transmission coefficient and solar irradiance prevent

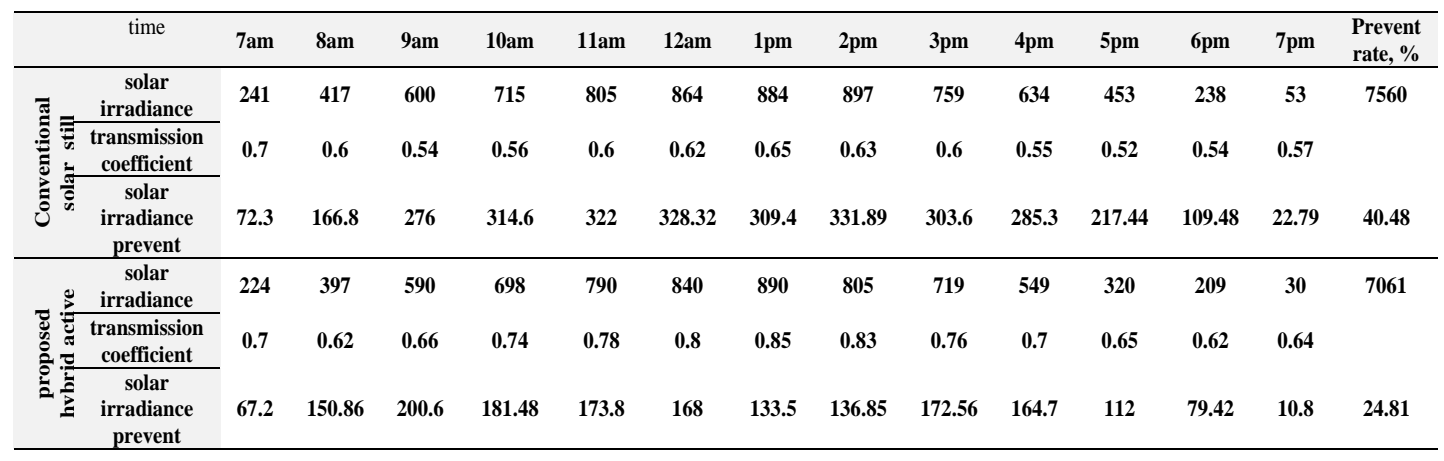

\subsection{Energy consumption}

Table 2 gives the daily of total observations, total Energy consumption, and total specific Energy consumption for the four experimental days at two different still moods. The data shows that the maximum irradiance was $7488 \mathrm{~W} / \mathrm{m}^{2}$.day from 25th May and 9th June and the minimum irradiance $7140 \mathrm{~W} / \mathrm{m}^{2}$.day from 30th May. Similarly, from Table 2, it is also found that maximum solar energy $26.959 \mathrm{MJ} / \mathrm{m}^{2}$.day, and minimum 
solar energy $25.704 \mathrm{MJ} / \mathrm{m}^{2}$.day. The ambient temperature was arrived to the maximum value $42{ }^{\circ} \mathrm{C}$ from 25 and 26 May and 9th June.

Table (2) the daily of total observations, total energy consumption, and total specific Energy consumption

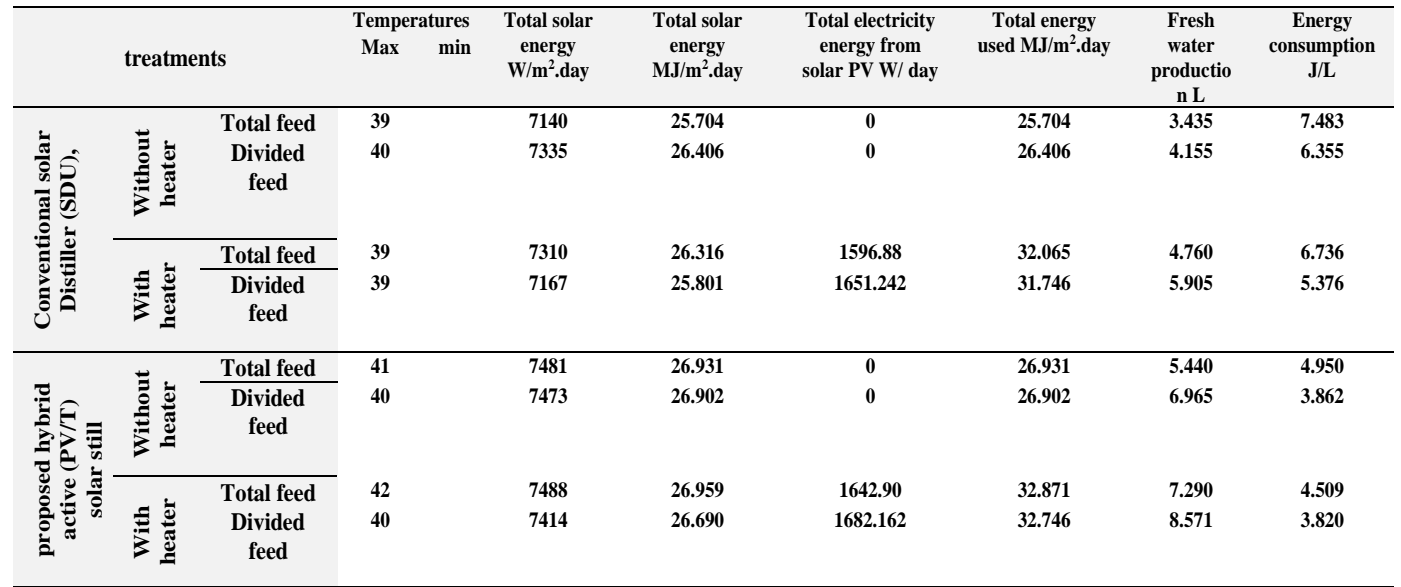

Similarly, from Table 2, it is also found that the proposed hybrid active (PV/T) solar still with heater and divided feed has the minimum specific Energy consumption it was $\mathbf{3 . 8 2 0} \mathrm{MJ} / \mathrm{L}$, means that the maximum utilization of energy. The maximum specific Energy consumption was 7.483MJ/L, it was found for the Conventional solar still without heater and Total feeding rate with minimum energy efficiency. About 3.763 MJ of the consumption of Energy for the production of a liter of fresh water was provided in the system of proposed hybrid active (PV/T) solar still with heater and divided feed, which saved about $49 \%$ of the energy consumption on production a liter of pure water. This is due to the separation of the condensation unit from the evaporation unit and the use of the thermal energy generated by the cooling process inside the condenser.

\subsection{Efficiency of the energy recycled from condensation}

Table 3 gives the daily of total heat energy of vaporization that saved in the condenser to preheat saline water for recycling, which is not lost to the environment in the proposed still and lost to the environment in the conventional solar still, the energy recycled from condensation unit, Rate of energy recycled to total energy and efficiency of recovering the energy from condensation. It is clear from the data that the value of large energy 
which is wasted in the Conventional solar still and saved in the proposed still. The minimum and maximum values of Energy recycled can be reused in the new design were $\mathbf{1 0 . 7 7} \mathrm{MJ} / \mathrm{m}^{2}$ and $\mathbf{1 7 . 0 1} \mathrm{MJ} / \mathrm{m}^{2}$.day with rate of total energy used $\mathbf{3 9 . 9 9} \%$ and $\mathbf{5 1 . 9 5 \%} \%$, which increases the distillation efficiency and increase the productivity of fresh water for the proposed still. Similarly, from Table 3, it is also found that the maximum energy loss from the condensation unit was $4.79 \mathrm{MJ} / \mathrm{m}^{2}$.day. And the minimum efficiency of recovered the energy from condensation unit (heat changer) was $\mathbf{7 8 . 6 6} \%$.

Table (3) the daily of total energy of vaporization, total energy losses, energy recycled and efficiency of the energy recycled.

\begin{tabular}{|c|c|c|c|c|c|c|}
\hline treatments & $\begin{array}{c}\text { Total } \\
\text { energy used } \\
\mathbf{M J} / \mathbf{m}^{2} \text {.day }\end{array}$ & $\begin{array}{c}\text { Energy of } \\
\text { vaporization } \\
\text { MJ/day }\end{array}$ & $\begin{array}{l}\text { Energy } \\
\text { losses } \\
\text { MJ/day }\end{array}$ & $\begin{array}{l}\text { Energy } \\
\text { recycled } \\
\text { MJ/day }\end{array}$ & $\begin{array}{l}\text { Rate of Energy } \\
\text { recycled to } \\
\text { Total energy }\end{array}$ & $\begin{array}{l}\text { Efficiency of } \\
\text { recovering the } \\
\text { energy from } \\
\text { condensation }\end{array}$ \\
\hline & & $\mathrm{q}_{\mathrm{e}}$ & $\mathrm{q}_{l}$ & $\mathrm{q}_{\mathrm{c}}$ & $\%$ & $\eta, \%$ \\
\hline $\begin{array}{l}\text { proposed hybrid total } \\
\text { feeding without heater }\end{array}$ & 26.931 & 13.69 & 2.92 & 10.77 & 39.99 & 78.66 \\
\hline $\begin{array}{c}\text { proposed hybrid total } \\
\text { feeding system with } \\
\text { heater }\end{array}$ & 32.871 & 18.47 & 3.64 & 14.83 & 45.12 & 80.30 \\
\hline $\begin{array}{c}\text { proposed hybrid } \\
\text { intermittent feeding } \\
\text { system without heater }\end{array}$ & 26.902 & 17.52 & 3.47 & 14.05 & 52.23 & 80.21 \\
\hline $\begin{array}{l}\text { proposed hybrid } \\
\text { intermittent feeding } \\
\text { system with heater }\end{array}$ & 32.746 & 21.81 & 4.79 & 17.01 & 51.95 & 78.03 \\
\hline
\end{tabular}

\subsection{Hourly Productivity of solar PV power.}

Productivity of solar PV power was affected by the electrical efficiency and ambient temperature. With rise of $1{ }^{\circ} \mathrm{C}$ in temperature the electrical efficiency of solar module decreases by $0.5 \%$. The maximum electrical conversion efficiency is obtained at $25{ }^{\circ} \mathrm{C}$ and $1000 \mathrm{~W} / \mathrm{m}^{2}$.

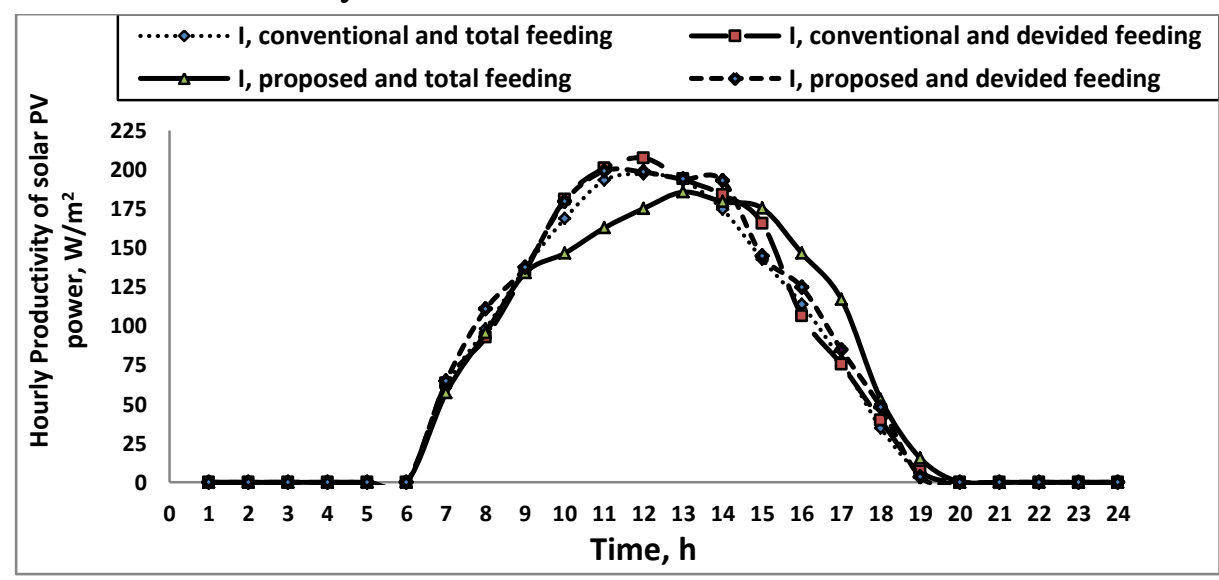

Fig. 5 Hourly Productivity of solar PV power for study days 
Figure 5 shows that the Productivity of solar PV started around 6:30 am and continued until after $7 \mathrm{pm}$. The maximum Productivity of solar PV reached to $207.35 \mathrm{~W}$ at $1 \mathrm{pm}$ during the days of the study. The maximum electrical efficiency obtained was approximately $12.43 \%$ at $1 \mathrm{pm}$. Figure 3 shows the variation of electrical productivity of PV system. In the morning the productivity was increasing and after $3 \mathrm{pm}$ there is drop of electrical efficiency due to less sunshine. The electrical productivity of $\mathrm{PV}$ varies between $40 \mathrm{~W}$ at the morning to $207 \mathrm{~W}$ at afternoon. When increasing the intensity of solar radiation, it affects in increasing the temperature inside the still and increase in the fresh water production, it is evident during the period of back.

\subsection{Hourly productivity of distillate water for all modes of solar still.}

Productivity of distillate water will be discussed through the effect of both the addition of electric heaters and the use of intermittent feeding system for the conventional and proposed still respectively.

The first one, when the still operating as a conventional solar still. The data from table 1 and fig. 6 shows that the daily output of distilled water was found to be $\mathbf{3 . 4 3 5} 1$ and $\mathbf{4 . 7 6 0} 1$ when the heaters was not used and used. The increasing in Productivity about $\mathbf{1 . 3 2 5} 1$ with $\mathbf{3 8 . 5 7 \%}$ if the full feeding system is used. But In the case of the use of intermittent feeding system and under the same conditions, the increasing in productivity was estimated about $\mathbf{1 . 7 5 0} \mathrm{l} / \mathrm{m}^{2}$ day with $\mathbf{4 2 . 1 1} \%$. Indicating that, the heaters lead to increasing the productivity about 38.57 and $\mathbf{4 2 . 1 1 \%}$ using different feeding systems. The effect of the use of intermittent feeding system in the productivity the data shows that increasing in productivity was estimated at about $\mathbf{0 . 7 5 0} \mathrm{l} / \mathrm{m}^{2}$ day with $\mathbf{2 0 . 9 5} \%$ and $\mathbf{1 . 1 4 5}$ with 24.04\% when the heaters was not used and used.

The second case, when the still operating as a proposed solar still. The data from table 1 and fig. 6 shows that the daily output of distilled water when the full feeding system used was increased from $\mathbf{5 . 4 4 0} 1$ to $\mathbf{7 . 2 9 0 1}$ (1.850 1 ) when the heaters was used with $34 \%$. But In the case of the use of intermittent feeding system and under the same conditions, the increasing in productivity was estimated about $\mathbf{1 . 6 0 6} 1 / \mathrm{m}^{2}$ day with 23.06\%. Indicating that, the heaters lead to increasing the productivity about 34 and $\mathbf{2 3 . 0 6} \%$ using different feeding systems. The effect of the 
use of intermittent feeding system in the productivity the data shows that increasing in productivity was estimated at about $\mathbf{1 . 5 2 5} \mathrm{l} / \mathrm{m}^{2}$ day with $\mathbf{2 8 . 0 3} \%$ and $\mathbf{1 . 2 8 1}$ with $\mathbf{1 7 . 5 7} \%$ when the heaters was not used and used. The minimum productivity of fresh water was estimated about $\mathbf{3 . 4 3 5}$ $1 / \mathrm{m}^{2}$ day, it was provided in the system of conventional solar still. The maximum productivity of fresh water in the system of proposed hybrid active (PV/T) solar still with heater and divided feed was estimated about $\mathbf{8 . 5 7 1} 1 / \mathrm{m}^{2}$ day. The increasing rate in the productivity about $149.50 \%$ was achieved using by using proposed solar still.
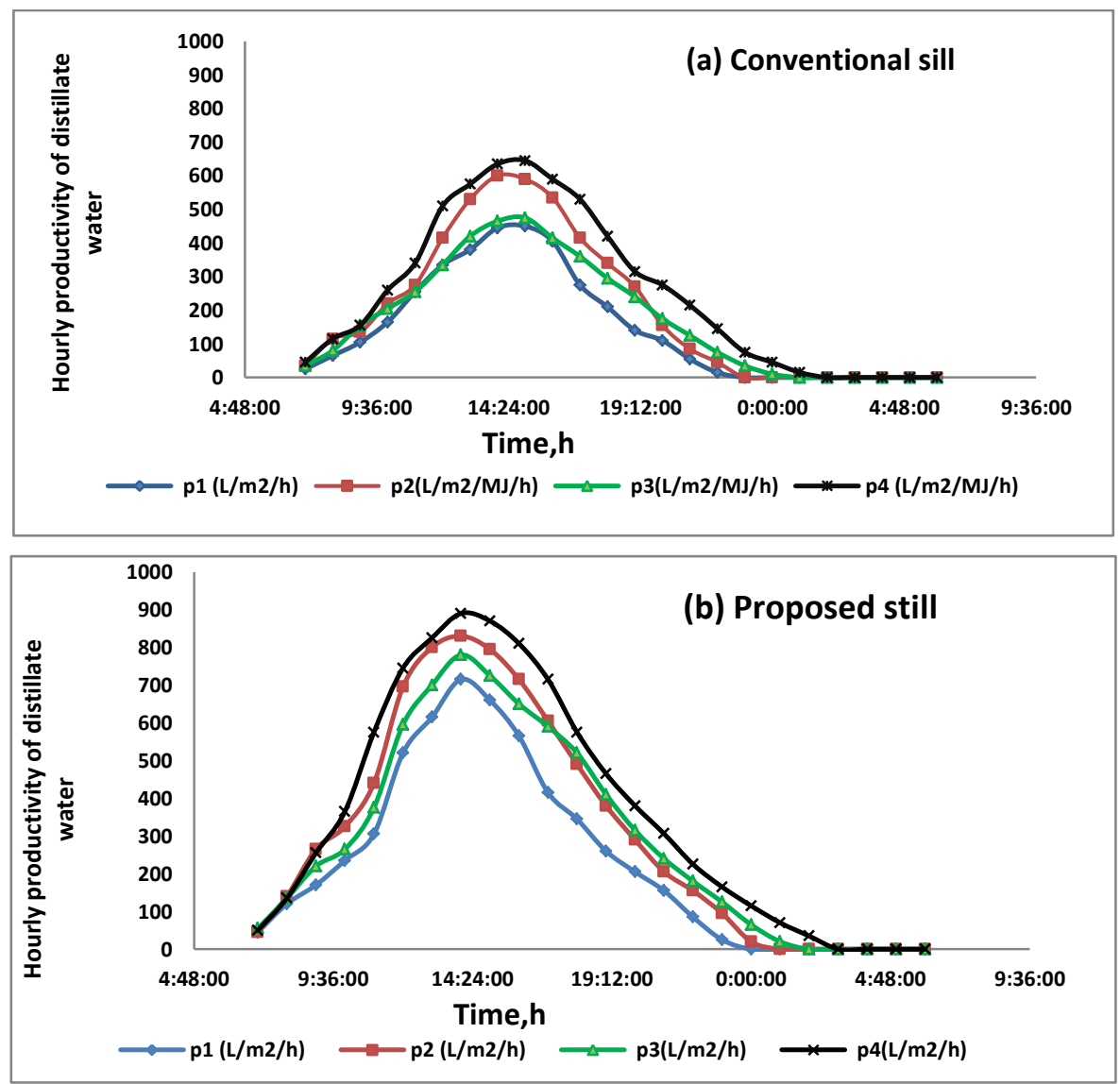

Fig. 6 Hourly productivity of distillate water for (a) Conventional sill (b) Proposed still

\subsection{Daily overall thermal efficiency of solar still.}

Eqs. (2)-(5) are evaluated to calculate the electrical and thermal efficiency of the proposed hybrid active (PV/T) solar still and the conventional passive solar still which is given in Fig. 7. The bar graph in 
Fig. 9 shows the variation in efficiency. The data in in Fig. 7 show that the overall efficiency of the conventional and proposed hybrid active (PV/T) solar still. The differences in water-charge systems into the basin as a complete and intermittent feeding system create a tremendous impact on thermal efficiency. The thermal efficiency of the conventional if the full and intermittent feeding system is used were found $\mathbf{3 2 . 3 0} \%$ and $\mathbf{3 8 . 0 8} \%$ when the heaters was not used respectively, and were found $\mathbf{3 5 . 8 5} \%$ and $\mathbf{4 5} \%$ when the heaters was used. But the overall thermal efficiency the proposed hybrid was $\mathbf{4 8 . 8 8} \%$ and $\mathbf{6 2 . 5 2} \%$ if the full and intermittent feeding and the heaters were not used respectively, and were found $\mathbf{5 3 . 5 7} \%$ and $\mathbf{6 8 . 2 8} \%$ when the heaters was used. The overall thermal efficiency was increased by $\mathbf{3 6} \%$ of the proposed hybrid active (PV/T) solar still is much higher than the conventional. This increasing is due to reasons; improvement the transmittance where is the percentage of solar radiation passing through the glass cover arrives to the maximum, loss of latent heat of condensation to the environment is minimized, and used to preheat saline water for recycling.

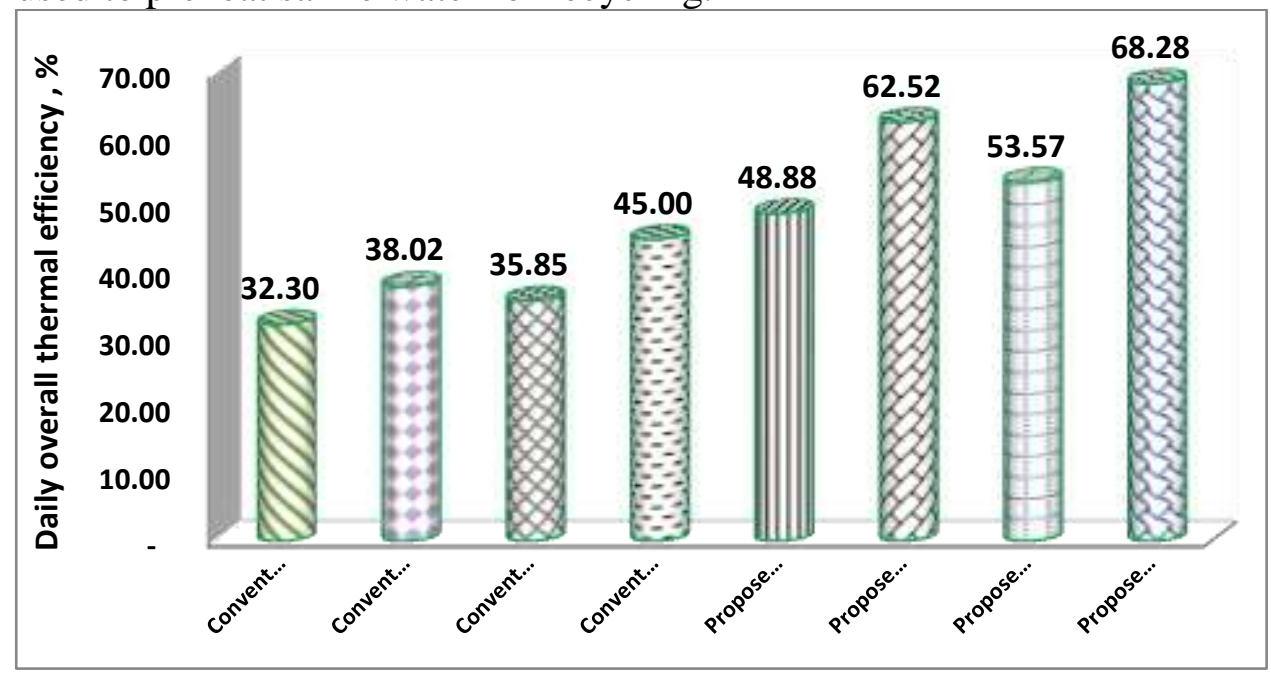

Fig. 7 Daily overall thermal efficiency of solar still

\section{CONCLUSIONS}

The experimental study of the two different solar still (conventional passive solar still and proposed hybrid solar still with heaters) with different water feeding rate have been presented. The conclusions have been made from the practical study as follows. 
2 The average temperature range of the water in the basin for the proposed hybrid active (PV/T) solar still was slightly higher than the conventional passive solar still. that is due to, it is under affected two factors the first one Leads to decreased the temperature (the exhaust fan) the second increased the temperature, it about $16 \%$ increase in the ratio of solar radiation transmission from the cover, the absorption of heat from the condenser surface and the heat produced by the heaters.

3 The minimum specific energy consumption was $3.820 \mathrm{MJ} / \mathrm{L}$ and the maximum specific Energy consumption was $7.483 \mathrm{MJ} / \mathrm{L}$, it is for the Conventional solar still. The proposed hybrid saved about $49 \%$ of the energy consumption to produce a liter of pure water.

4 The minimum and maximum values of energy recycled that can be reused in the new design were $10.77 \mathrm{MJ} / \mathrm{m}^{2}$.day and $17.01 \mathrm{MJ} / \mathrm{m}^{2}$.day with rate of $39.99 \%$ and $51.95 \%$ from total energy used, which increases the distillation efficiency and increase the productivity of fresh water for the proposed still.

5 The water production from the proposed still was about 149\% higher than the passive still during the experimental days.

6 The overall thermal efficiency for the proposed hybrid active solar still (PV/T) was increased by $36 \%$ of the conventional solar still.

\section{5- REFERENCES}

Abu-Arabi M., Y. Zurigat, H. Al-Hinai, S. Al-Hiddabi, Modeling and performance analysis of a solar desalination unit with double glass cover cooling, Desalination 143 (2002) 173-182.

Akash B., M. Mohsen, W. Nayfeh, Experimental study of the basin type solar still under local climate conditions, Energy Convers. Manag. 41 (2000) 883-890.

Al-Hinai H., M.S. Al-Nassri, B.A. Jubran, Effect of climatic, design and operational parameters on the yield of a simple solar still, Energy Convers. Manag. 43 (2002) 1639-1650.

Al-Karaghouli A.A.,W.E. Alnaser, Performances of single and double basin solar stills, Appl. Energy 78 (2004) 347-354.

Badran O.O., Experimental study of the enhancement parameters on a single slope solar still productivity, Desalination 209 (2007) 136-143. 
El-Sebaii A.A., Effect of wind speed on active and passive solar stills, Energy Convers. Manag. 45 (2004) 1187-1204. evaluation of an active solar distillation system. Int. J. Energy Res. 31, 14651482.

Ghoneyem A., A. Ileri, Software to analyze solar stills and an experimental study on the effects of the cover, Desalination 114 (1997) 37-44.

Hiroshi T., Tilted wick solar still with external flat plate reflector: optimum inclination of still and reflector, Desalination 249 (2009) 411-415.

Je J., J. Ping Lu, T.T. Chow, W. He, G. Pai, A sensitivity study of a hybrid photovoltaic/ thermal water heating system with natural circulation, Appl. Energy 84 (2007) 222-237.

Kaushal A., Varun, Solar stills: a review, Renew. Sustain. Energy Rev. 14 (2010) 446-453.

Khalifa A.J.N., A.M. Hamood, Effect of insulation thickness on the productivity of basin type solar stills: an experimental verification under local climate, Energy Convers. Manag. 50 (2009) 2457-2461.

Khalifa A.J.N., A.M. Hamood, On the verification of the effect of water depth on the performance of basin type solar still, Solar Energy 83 (2009) 1312-1321.

kumar B. P., D. P. Winstona, P. Pounrajb, A. M. Manokarc, R. Sathyamurthyd, A.E. Kabeelf., 2017. Experimental investigation on hybrid PV/T active solar still with effective heating and cover cooling method. Desalination (2017), "http://dx.doi.org/10.1016/i.desal.2017.11.007."

Kumar S., G. Tiwari, H. Singh, Annual performance of an active solar distillation system, Desalination 127 (2000) 79-88.

Matthews S., "Desalination in Middle East set to grow," Home/Utilities Middle East. 5 April 2009.

Monowe P., M. Masale, N. Nijegorodov, V. Vasilenko, A portable single-basin solar still with an external reflecting booster and an outside condenser, Desalination 280 (2011) 332-338.

Nafey A.S., M. Abdel Kader, A. Abdelmotalip, A.A. Mabrouk, Parameters affecting solar still productivity, Energy Convers. Manag. 41 (2000) 1797-1809. 
Omar M.N., (2011) Environmental Control of Some Vegetable Crops Inside Greenhouse Ph.D. Thesis, University of Menofia, Egypt.

Omar, M.N., A.A. Samak, and M.H. Keshek, (2018). Simulation Model of Using the Electricity and Exhaust Gas Heat Generated from Poultry Litter Waste in Their House. EurAgEng 2018 conference "New Engineering Concepts for Valued Agriculture", 8 - 12 July 2018, Wageningen, the Netherlands. (Conference proceedings Pages 530-539). "http://ageng2018.com/sites/default/files/Proceedings.docx"

Pal, P., Yadav, P., Dev, R., Singh, D., 2017. Performance analysis of modified basin type double slope multi-wick solar still. Desalination 422, 68-82.

Rubioa E., M.A. Porta, J.L. Fernandez, Cavity geometry influence on mass flow rate for single and double slope solar stills, Appl. Therm. Eng. 20 (2000) 1105-1111.

Salam,Y.A. (2011) Simulation model for seawater distillation by solar energy Ph.D. Thesis, University of Menofia, Egypt.

Setoodeh N., R. Rahimi, A. Ameri, Modeling and determination of heat transfer coefficient in a basin solar still using CFD, Desalination 268 (2011) 103-110.

Sharshir S.W., Nuo Yang, G. Peng , A.E. Kabeel, Factors affecting solar stills productivity and improvement techniques: A detailed review. Applied Thermal Engineering 100 (2016) 267-284w

Shukla S.K., V.P.S. Sorayan, Thermal modeling of solar stills: an experimental validation, Renew. Energy 30 (2005) 683-699.

Singh H.N., G.N. Tiwari, Monthly performance of passive and active solar stills for different Indian climatic condition, Desalination 168 (2004) 145-150.

Singh, D.B., Tiwari, G.N., Al-Helal, I.M., Dwivedi, V.K., Yadav, J.K., 2016b. Effect of energy matrices on life cycle cost analysis of passive solar stills. Solar Energy 134, 9-22.

Taha A.T., (2010) Estimation of Houraly Global Solar Radiation in Egypt using Mathematical Model. MISR,J.Ag. Eng.27 (4):233247.

Tiwari A.K., G.N. Tiwari, Effect of water depths on heat and mass transfer in a passive solar still: in summer climatic condition, Desalination 195 (2006) 78-94. 
Tiwari A.K., G.N. Tiwari, Thermal modeling based on solar fraction and experimental study of the annual and seasonal performance of a single slope passive solar still: the effect of water depths, Desalination 207 (2007) 184-204.

Tiwari G.N., Solar Energy: Fundamentals, Design, Modelling and Applications, CRC Publication/Narosa Publishing House, New Delhi/New York, 2002.

Tiwari, G.N., Dimri, V., Singh, U., Chel, A., Sarkar, B., 2007. Comperative thermal performance

Tripathi R., G.N. Tiwari, Performance evaluation of a solar still by using the concept of solar fractionation, Desalination 169 (2004) 6980 .

Tripathi R., G.N. Tiwari, Thermal modeling of passive and active solar stills for different depths of water by using the concept of solar fraction, Solar Energy 80 (2006) 956-967.

Velmurugan V., K. Srithar, Performance analysis of solar stills based on various factors affecting the productivity - a review, Renew. Sustain. Energy Rev. 15 (2011) 1294-1304.

Voropoulos K., E. Mathioulakis, V. Belessiotis, Experimental investigation of the behavior of a solar still coupled with hot water storage tank, Desalination 156 (2003) 315-322.

Zurigat Y.H., M.K. Abu-Arabi, Modelling and performance analysis of a Regenerative solar desalination unit, Appl. Therm. Eng. 24 (2004) 1061-1072.

\section{الملخص العربي}
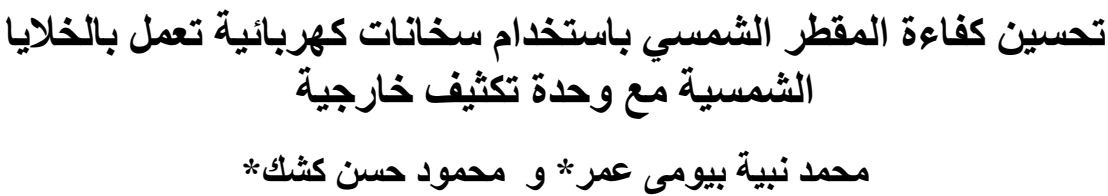

المياه و الطاقة هما محوري التنمية لأى دولة ويعتبران شريان الحياة فلا يسنطيع أحد ان يعيش التيش

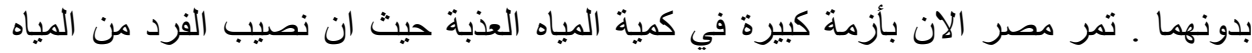

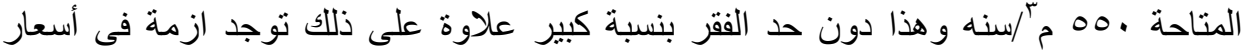

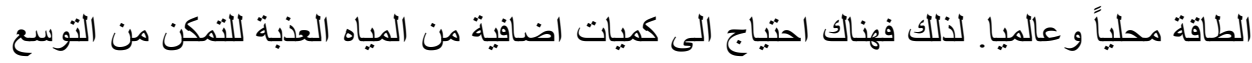

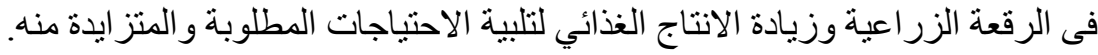

*مدرس بقسم الهندسة الزراعية والنظم الحيوية ـ كلية الزراعة - جامعة المنوفية. 
ويمكن توفير جزء من كميات المياه المطلوبة وذللك بزيادة كفاءة المقطرات الثمسية المستخدمة

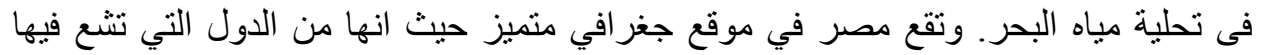

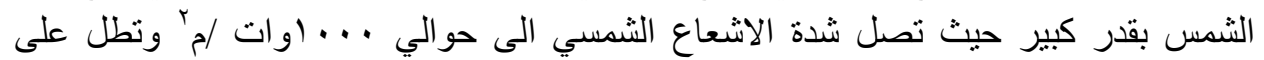

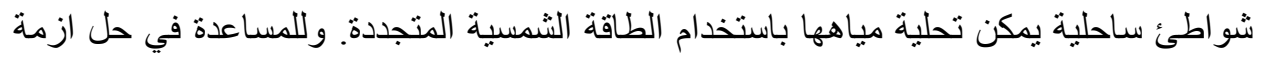

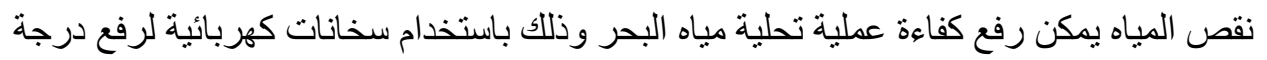

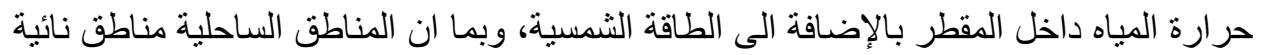

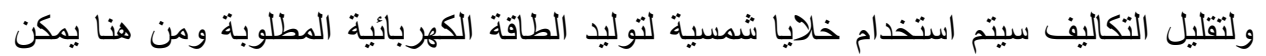

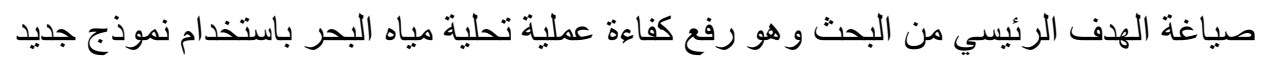

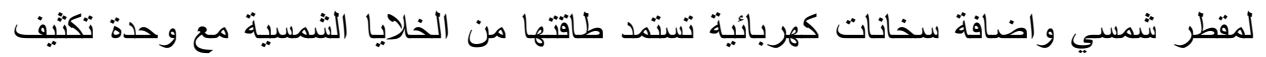

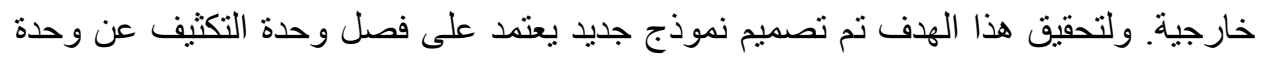

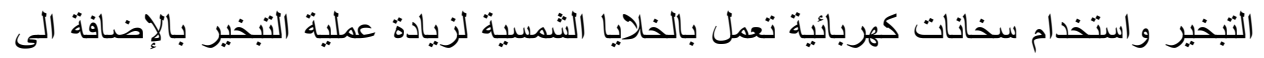
الطاقة الثمسية المستخدمة وكذللك القدرة على تبريد وحدة التكثيف واعادة استخدام الطاقة

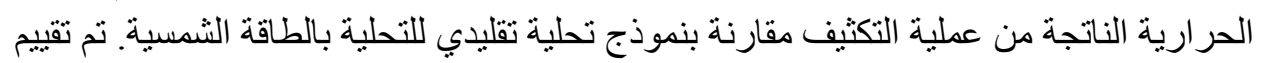

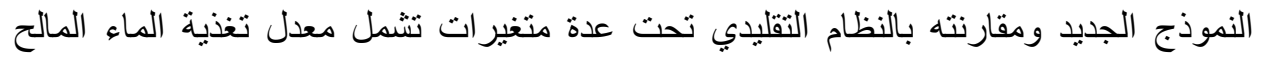

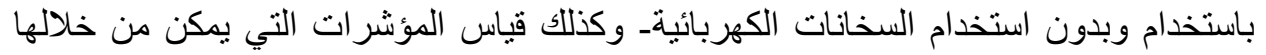

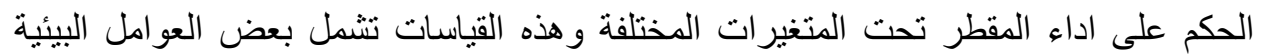

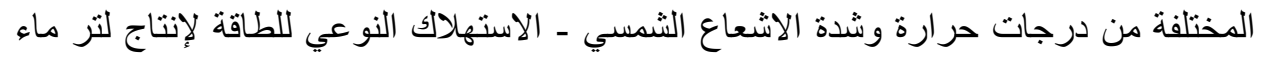

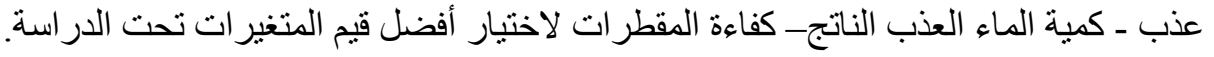

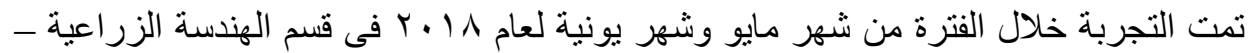

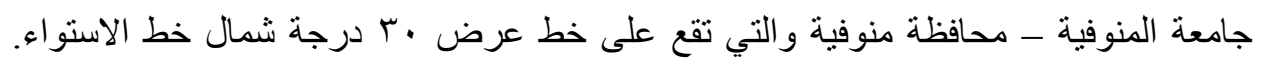

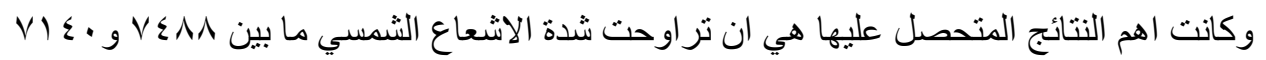

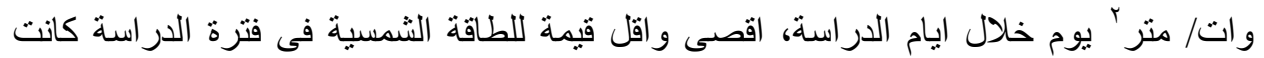


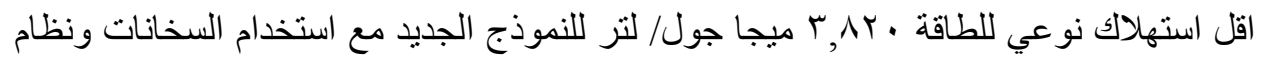

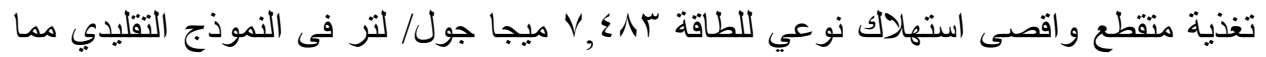

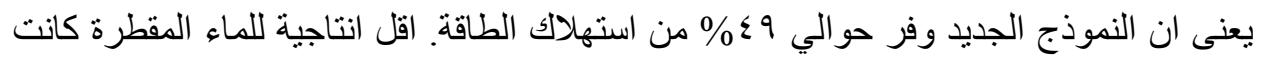

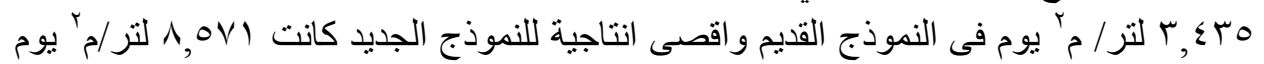

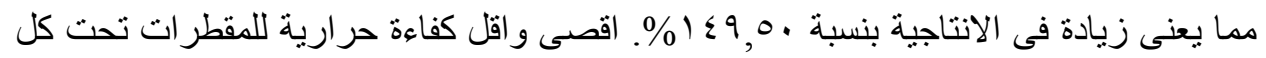

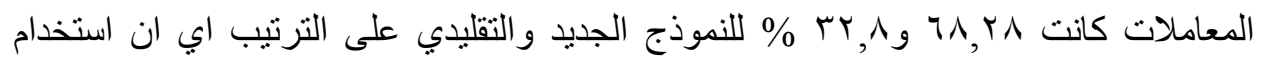

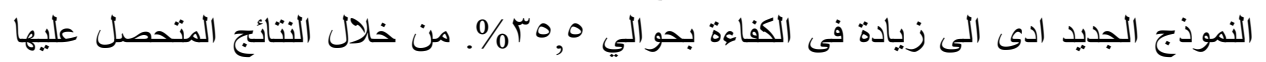

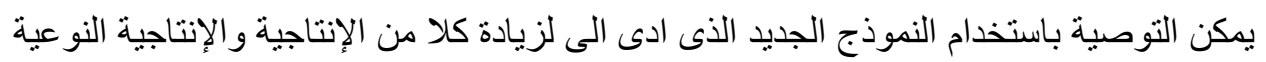

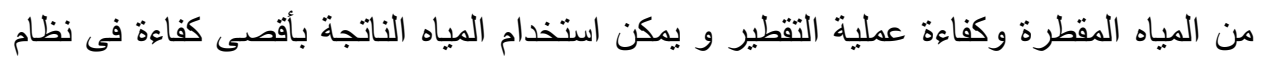

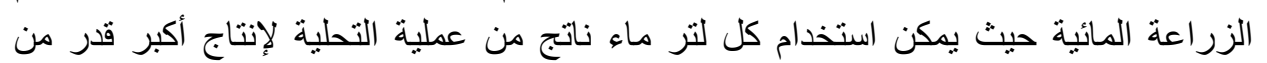

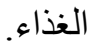

